\title{
The United Nations Conference on Sustainable Development: forty years in the making
}

\author{
Björn-Ola Linnér \\ Department of Water and Environment Studies and Centre for Climate Science and Policy \\ Research, Linköping University, 58183 Linköping, Sweden, and Center for Science and \\ Technology Policy Research, University of Colorado, Boulder, CO 80309-0488, USA; \\ e-mail: bjorn-ola.linner@liu.se
}

\section{Henrik Selin}

Department of International Relations, Boston University, Boston, MA 02215, USA; e-mail: selin@bu.edu

Received 26 October 2012; in revised form 1 May 2013

\begin{abstract}
The United Nations Conference on Sustainable Development (UNCSD) was mandated to focus on: (i) institutional frameworks for sustainable development and (ii) the green economy in the context of sustainable development and poverty eradiation. Analyzing the UNSCD from a historical perspective, we address three questions. First, what is the role of UN conferences on environment and development? Second, how were the UNCSD debates and outcomes connected to over forty years of environment and development cooperation? Third, how may the UNCSD shape ongoing efforts to forward the sustainable development agenda? We begin by summarizing the main arguments of supporters and critics of UN conferences. Next, we examines two sets of institutional frameworks issues: (a) institutional creation and reforms and (b) institutional complexity and participation. This is followed by an examination of two kinds of green economy issues: (1) state-centered economic debates and (2) human-development-focused debates. In the final section we examine opportunities and limitations for making progress on sustainable development. We argue that the UNCSD did little to advance institutional reforms, but that the initiative to formulate Sustainable Development Goals has the potential to significantly influence the sustainable development agenda.
\end{abstract}

Keywords: United Nations, conferences, sustainable development, environment, Millennium Development Goals

\section{Introduction}

Despite being criticized for lack of effectiveness, the UN maintains a central role in global governance. To breathe new life into a stagnating environment and development agenda, the UN Conference on Sustainable Development (UNCSD) was held in Rio de Janeiro in June 2012. In the December 2009 resolution to organize the UNCSD, the UN General Assembly stated that its objective should be to secure renewed political commitment for sustainable development, assess progress to date and remaining gaps in implementing outcomes of earlier conferences, and address new and emerging challenges. More specifically, the UNCSD should focus on: (i) a green economy in the context of sustainable development and poverty eradication and (ii) the institutional framework for sustainable development (UNGA, 2010). This broad conference mandate created an opportunity for the UNCSD to take a comprehensive approach to complex and interrelated issues, though there was also a risk that the large agenda would prevent participants from paying sufficient attention to the many issues competing for attention. 
UN member states and organizers often situate conferences in their historical context, sometimes to elevate their political significance by stressing how they are linked to other important events. This is evident in the UN General Assembly resolution as well as in the semiofficial name of the UNCSD, which is frequently referred to as 'Rio+20' to mark its connection to the much-heralded UN Conference on Environment and Development (UNCED) convened in Rio de Janeiro in 1992 (the 'Rio Earth Summit'). In addition, analysts and participants paid homage to the UN Conference on the Human Environment (UNCHE) held in Stockholm in 1972 as well as to the 2002 World Summit on Sustainable Development (WSSD) in Johannesburg and the special meeting of the United Nations Environment Programme (UNEP) in Nairobi in 1982. All these large gatherings of states and nonstate actors are key symbolic and political events in over four decades of environment and development cooperation. They have also attracted much praise and criticism.

During the preparatory process, analysts and participants expressed hopes that the UNCSD would put its mark on history. Building on the debates and decisions of earlier conferences, they hoped that the UNCSD would deliver meaningful institutional and political change within the two conference themes (Bigg, 2011). Others regarded the UNCSD with more skepticism. As UN bodies and member states began the conference preparations, skeptics saw few opportunities for real and long-lasting transformation (Andresen, 2012). Since the conference, analysts and observers have also differed in their assessment of the UNCSD (Clémençon, 2012a; Haas, 2012; Powers, 2012). In any case, however, the UNCED cannot be regarded as an isolated event, but as a recent episode in a long process. Historical linkages are also evident in the main conference outcome document entitled The Future We Want (UNGA, 2012). Consequently, any analysis of the UNCSD must consider how its organization, debates, and decisions relate to earlier policy processes and outcomes as well as examine how it may influence postconference activities.

In this paper we analyze the UNSCD by addressing three questions. First, what is the role of UN conferences on environment and development? Second, how were UNCSD debates and outcomes connected to over forty years of environment and development cooperation? Third, how may the UNCSD shape ongoing efforts to advance the sustainable development agenda? In short, we argue that the UNCSD did little to advance an institutional agenda characterized by path dependency and inertia. Instead, more dynamic developments took place in the human development area. In particular, the formulation of Sustainable Development Goals (SDGs) may prove to be significant. This initiative builds off the Millennium Development Goals (MDGs) and coincides with an effort to go beyond a traditional focus on gross domestic product (GDP) for measuring human well-being. As the work on establishing the SDGs progresses, it is essential that they come with a robust system for monitoring and reviewing progress across critical sustainable development indicators.

To address the three questions above, we surveyed the literature on UN environment and development conferences and reviewed the preparatory work, declarations, and action programs of the 1972, 1982, 1992, 2002, and 2012 conferences on environment and development as well as other key UN documents. We examined the context of key concepts, changes in problem definitions, diagnoses of causes of environmental degradation and suggested remedies, and identifications of key institutions and actors, comparing the ways in which the content and recommendations of The Future We Want are similar to and different from those of earlier conference documents. In the next section we discuss the UN conference system and sustainable development politics. This is followed by two sections examining institutional frameworks and green economy issues, respectively, using earlier conferences as benchmarks when tracing important continuities and changes over time. In the final section we return to the issue of what can reasonably be expected from UN conferences, discussing 
opportunities for and constraints on advancing the faltering environment and development agenda in the aftermath of the UNCSD.

\section{UN conferences and sustainable development politics}

The UN supports cooperation in many ways, including through convening ad hoc conferences across a wide range of political, economic, and social issue areas (Schechter, 2005). Sometimes these conferences are officially labelled summits, as they include extensive highlevel participation of heads of states and governments. Some of the largest UN meetings in terms of state participation have addressed environment and development issues, dating back to the Stockholm Conference. These gatherings over the past four decades serve as important reference points in gauging the state of policy making. While UN conferences remain largely state-centric, the participation of intergovernmental organizations (IGOs) and nongovernmental organizations (NGOs) in these meetings and associated political negotiations has grown tremendously over the years. The UN conference system, however, is under increased scrutiny. What do supporters and critics say about the role of UN conferences?

\section{The roles of UN conferences}

UN conferences are based on the sovereign equality of states and the principle of inclusive multilateralism. The UN Charter gives member states the formal right to participate on equal terms in conference debates and decisions. This approach to organizing conferences is related to the idea that broader memberships are more representative and thereby more legitimate (Hafner-Burton et al, 2012). From this perspective, formal justice and procedural justice for state participation are essential to ensuring the validity of conference debates and outcomes. The more diverse representation of countries is accordingly considered better because it allows a greater range of opinions to be voiced and facilitates the adoption of generally beneficial decisions that ensure "the autonomy of the many rather than the few" (Eckersley, 2012, page 27). The more recent official expansion in conference participation to include civil society groups is based on related values concerning the benefits of openness and transparency.

While not being blind to their limitations, proponents of UN conferences and the type of inclusive multilateralism they represent argue that they fulfil a wide range of governance functions (Clémençon, 2012a; Death, 2011; DeSombre, 2006; Hjerpe and Linnér, 2010; Seyfang, 2003). Conferences can be important instruments for setting global priorities, raising awareness, and focusing attention on issues that may at times not receive the consideration they deserve (as there is growing competition between issues on an increasingly crowded world agenda). In this respect, conferences are high-profile platforms for framing problems, formulating legal principles and norms, supporting the creation of new organizations and forums, generating and disseminating information, and setting political expectations and standards of conduct. Conferences also function as political arenas connecting a broad range of state and nonstate actors that may otherwise not engage each other, allowing them to exchange visions and interests, or clarify disagreements and share best practices (Powers, 2012).

Even the most vocal supporters of UN conferences acknowledge that they result in limited direct accomplishments. Those who believe in their value, however, often claim that it can be difficult to gauge a conference's significance in its immediate aftermath. The importance of a conference often has more to do with its ability to influence political agendas and steer subsequent activities in other forums than with what happens at the meeting itself. Supporters stress that some criticism of UN conferences takes too narrow an approach to conceptualizing their effectiveness. They argue that it is necessary to look at both their direct and indirect influence over longer periods. For example, the national reporting on domestic actions on environmental issues, requested by the conference secretariat during the preparations for the 
Stockholm Conference, spurred institutional change and legislation in many countries. The first and second waves of establishing environmental ministries also came in the run-up to and aftermath of the Stockholm and the 1992 Rio conferences, respectively (Meyer et al, 1997; Selin and Linnér, 2005, pages 35-36).

In contrast, critics of megaconferences argue that their large number of participants impedes collective action, as these critics value effective problem solving over broad participation (Olson, 1968). While claims of negative impacts of expanded participation have been challenged (Kahler, 1992), criticism of large meetings has led to discussions of alternative structures, including greater use of smaller venues. In some cases such proposals are self-serving: major countries with access to forums such as G-20 know that they will still be at the table (and may even see their relative influence increase) in a smaller setting. In other cases, analysts seek to reconcile perceived tensions between inclusion and exclusion by advocating for minilateralism "based on 'common but differentiated representations', that is, representation by the most capable, the most responsible, and the most vulnerable" (Eckersley, 2012, page 26). Even so, there is no objective way to decide who should be included, and many of the excluded are likely to express resentment and question the authority of decisions with global implications.

Some skeptics have derided UN conferences for being too resource intensive to plan and host, producing only broad-brush political statements quickly ignored by states and national politicians (Andresen, 2012; Haas, 2012). Others criticize them for serving only to solidify the existing political system and its inequalities, rather than promoting more fundamental change (Bernstein, 2001). If the environment and development conferences are judged by their own policy goals stated in declarations and action plans, they have largely fallen short. The 1972 Stockholm Conference drew unprecedented attention to issues of the human environment, but subsequent years of cooperation and policy making have produced mixed results. A growing global economy has raised standards of living for large segments of the world's population, but continuing poverty and other social problems as well as unprecedented resource use and ecological degradation pose formidable governance challenges (UNDP, 2010).

\section{Global politics of sustainable development}

Global cooperation on sustainable development, including through the holding of UN conferences, has attracted much scholarly attention. Some of the relevant literature looks at the politics of environment and development issues from a comparatively short historical perspective (Faucheux et al, 1996; Goodland, 1995; Howarth, 1997). These studies often start their analysis in the 1980s with the creation and work of the World Commission on Environment and Development (the 'Brundtland Commission'). However, earlier extensive cooperation over the preceding two decades fed into the Stockholm Conference and shaped a wide range of subsequent multilateral activities, including the Brundtland Commission and its landmark report Our Common Future (World Commission on Environment and Development, 1987). Consequently, any comprehensive analysis of global sustainable development cooperation needs to look back at least to the 1960s and the decision to organize the UNCHE (Dodds et al, 2012; Engfeldt, 2009; Quental et al, 2011; Selin and Linnér, 2005).

The UN conferences have stressed global commonalities and a shared planetary destiny for all countries and people as a basis for promoting collective action. This view was already embodied in the Stockholm Conference theme, Only One Earth, as the UNCHE declaration called "for a common outlook and for common principles to inspire and guide the peoples of the world in the preservation and enhancement of the human environment" (UN, 1972a, page 1). Similarly, the Brundtland Commission entitled its report Our Common Future, the Rio 1992 meeting was called the 'Earth Summit' and adopted a global agenda for the 21 st century, and the UNCSD outcome document was entitled The Future We Want. 
Some analysts, however, have criticized this notion that countries and people share perspectives and interests, arguing that this downplays real and fundamental differences in desires and needs between and insides countries (Guha and Martinez-Alier, 1997; Sachs, 1993). Although a central goal of the UN conferences has been to seek to bridge differences in perspectives and interests, many debates also have been marked by much more controversy than agreement.

At a very basic level, sustainable development is seen to rest on the three environmental, economic, and social pillars - the 'triple bottom line' for human well-being (Jordan, 2008; Lele, 1991; Sachs, 2012). The UN conferences have paid varying levels of attention to the three pillars as well as to specific topics within each of them. Since the Stockholm Conference, North-South politics between industrialized and developing countries has significantly affected environment and development policy, as there is a lack of agreement regarding the trade-offs and synergies among the three pillars. However, the homogeneity of these two groups of countries based on their general positions in the postcolonial world economy should not be exaggerated. Ongoing changes - including the growing influence of major developing countries such as Brazil, South Africa, China, and India - are influencing political and economic relationships, including the allocation of responsibilities and the application of the principle of common but differentiated responsibility (Perkins, 2013; UNDP, 2013).

Over the years, many institutional developments and policy outcomes have reflected evolving state interests, even though these typically result from extensive compromise in the perennial search for consensus. There is also much evidence of path dependency - that is, one UN conference sets events moving along a certain trajectory that limits the range of subsequent actions and decisions, including the agenda and outcomes of subsequent meetings (Fiertos, 2011). In this complex historical context of changing national interests and institutional rigidity, how were UNCSD debates and outcomes connected to over forty years of global environment and development cooperation? In the next two sections we take a historical perspective by analyzing the UNCSD's two broad themes of institutional frameworks for sustainable development and the green economy in the context of sustainable development and poverty eradiation. In both these areas there are continuous tensions between efforts to develop multilateral structures and policies and the need to satisfy many different national perspectives and interests.

\section{Institutional frameworks for sustainable development}

In global cooperation on environment and development, institutional design issues have always been both central and controversial. At their core they concern how governance should be structured and who gets to participate. Many institutional developments reflect the interests of the most powerful states, even though they also typically involve frequent bargaining and path dependency. Institutional creation is also an area in which the UN conferences have had a noticeable impact. They have been used to develop international law and customary practice, including with respect to state obligations and responsibilities. The conferences have also been instrumental in creating new IGOs, such as UNEP and the Commission on Sustainable Development (CSD), and in guiding the activities of UN organizations toward policy goals agreed on in conference documents and elsewhere. Focusing on how institutional debates have evolved over time, in this section we examine two major sets of issues: (i) institutional creation and reform and (ii) institutional complexity and participation.

\section{Institutional creation and reform}

Institutional expansion was already a main topic at the Stockholm Conference, including with respect to the establishment of UNEP (Ivanova, 2007; Selin and Linnér, 2005). During the sometimes highly contentious debate on creating a separate environmental body, 
UN Secretary-General U Thant asked the critical question:

"Do the sovereign nations of the world have the courage and the vision to set up and support such an agency now, and thus, in the interest of future generations of life on earth, depart radically from the hitherto sacred path of national sovereignty?" (Cordier and Harrelson, 1977, page 350).

Discussions of UNEP's preferred mandate were also marked by stark political differences. A few countries, stressing the importance of collective governance, promoted making UNEP a specialized agency and giving it basic regulatory powers (Engfeldt, 1973). This, however, was fiercely rejected by most other countries, fearing an erosion of state sovereignty. Largely answering Thant's question in the negative, states refused to provide UNEP with much independent decision-making authority.

In 1972 the UN General Assembly constituted UNEP as a program to coordinate and foster cooperation without giving it the status of a specialized agency. UNEP has been forced to rely primarily on voluntary financial contributions from a small number of countries. Funding has been both limited and inconsistent. UNEP's annual budget was a mere US \$217 million in 2010, versus US \$4 billion for the World Food Programme and close to US $\$ 4.8$ billion for the United Nations Development Programme (UNDP) (Ivanova, 2012). Nevertheless, UNEP has overseen a great deal of cooperation despite its limited budget and the relatively small size of its Secretariat. UNEP has also frequently collaborated with other organizations, such as the UNDP, the Food and Agriculture Organization, and the World Health Organization. In addition, UNEP has served as an important forum for major NGOs, including the International Council for Science, the International Union for Conservation of Nature, and the World Wildlife Fund (Holdgate, 1999).

UNEP launched the largely failed concept of ecodevelopment in the mid-1970s in an effort to reconcile ecological protection efforts with social and economic development, but over the years UNEP has focused on mainly environmental issues. As the concept of sustainable development gained popularity in the 1980s, states began considering the need for a new body to operate alongside UNEP and other UN organizations. As part of its report, the Brundtland Commission suggested a UN Board for Sustainable Development, which, following a recommendation of the Rio Earth Summit in 1992, was realized in the form of the CSD. In many ways similar to the UNEP-related discussions twenty years earlier, concerns about ceding national sovereignty meant that countries were willing to give the CSD only a relatively weak mandate; it was tasked with promoting sustainable development-including local, national, and global initiatives implementing Agenda 21 - but was given very little independent authority (Kaasa, 2007).

The establishment of UNEP and the CSD had made countries increasingly wary of creating additional resource-demanding UN bodies. Instead, political debates gradually shifted to how better to coordinate existing forums and organizations. The dominant reform discussions display an institutional path dependency as they center on ways to advance incremental reform, rather than on how to fundamentally change the system. Even these debates, however, are politically contentious, as some national interests have changed over the past forty years while others have remained largely the same. Much of the coordination debate at the UNCED focused on unobtrusive ways to better capture management synergies across institutions, as there can be both considerable overlaps and gaps between different structures and forums (Biermann and Bauer, 2005; Vijge, 2013). This includes trying to find ways to better link the goals and activities of major UN organizations addressing sustainable development issues in various ways. There are also ongoing efforts to better coordinate policy making across major multilateral environmental treaties, as a way to strengthen the environmental pillar of sustainable development (Selin, 2010). 
In particular, the European Union and some African countries have advocated transforming UNEP into a United Nations Environment Organization (Earth Negotiations Bulletin, 2012). Although there is growing political support for upgrading UNEP to a UN specialized agency, most industrialized and developing countries have resisted this initiative for a variety of reasons, including a continued unwillingness to cede sovereignty and concerns about increased funding demands (Ivanova, 2012). Instead, at the UNCSD countries could agree on only less substantial reforms, including expanding membership in the UNEP Governing Council (article 88). In addition, most countries believe that the CSD's weak review process has been unsatisfactory. Therefore, the UNCSD instructed the UN General Assembly to create a new 'high-level political forum' on the implementation of sustainable development to replace the CSD (articles 84-86). This process started at the UN General Assembly's 68th session in the fall of 2012. So far, the outcome of these discussions is uncertain, but sovereignty and funding issues continue to be critical here as well.

Institutional reform debates leading up to the UNCSD also focused on international economic organizations. Economic issues always occupied an important position on the conference agendas and also received considerable attention from the Brundtland Commission. Going into the UNCSD, many policy advocates and at least some countries, mainly European, hoped to see better integration of the World Trade Organization (WTO), the World Bank, and other economic organizations into the very center of the sustainable development agenda (Clémençon, 2012b; Meléndez-Ortiz, 2011). As part of this, they called for fundamental shifts in IGOs and macroeconomic policy instruments relating to the structures and principles of international trade and finance (Najam and Selin, 2011). The UNCSD, however, did little to advance this process. Instead, continuing debates about potential reforms to the mandates and roles of the major trade and finance organizations will have to take place within the respective bodies, as many countries remain skeptical of significantly altering their provisions, preferring the status quo.

\section{Institutional complexity and participation}

At the UNCSD there were additional debates on how to address institutional complexity and participation. Building on discussions dating back to the Rio Earth Summit in 1992 and the adoption of Agenda 21, The Future We Want recognizes that integrated governance across "local, subnational, national, regional and global levels" is necessary to move the sustainable development agenda forward (article 76). This reflects increased attention to multilevel governance. Improved governance involves better connecting institutions across the global, regional, national, and local governance levels. Related to this, The Future We Want highlights the role of "partnerships among cities and communities" in advancing sustainable development (article 136). Although both the Stockholm Declaration and Agenda 21 recognize local governments, achieving sustainable cities has received much greater attention in recent years. This is partly because it is estimated that two thirds of the over nine billion people expected to be living in 2050 will reside in cities (many of which are located in ecologically vulnerable coastal areas).

The attention paid to cities at the UNCSD is also part of an expanded focus on nonstate actors. Nation-states no longer represent the sole locus of power. Authority is increasingly located beyond national governments, involving networks of local governments, advocacy groups, social movements, and business organizations (Biermann, 2010; Cerney, 2010; McGrew and Held, 2002). At the Stockholm Conference in 1972 municipalities were acknowledged for mainly their problems (UN, 1972b); the same was true of the 1992 and 2002 conferences (UN, 1992a; 2002). Cities were urged to start organizing reactive work to counter sustainable development stressors. Agenda 21 concluded that "rapidly growing cities, unless well managed, face major environmental problems. The increase in both the number and size 
of cities calls for greater attention to issues of local government and municipal management" (UN, 1992b, section 5.3). In contrast, the UNCSD stressed the positive and proactive position of cities as an important part of the solution: "We recognize that partnerships among cities and communities play an important role in promoting sustainable development" (UN, 2012, page 137).

The Future We Want, furthermore, frequently refers to the importance of major groups and other stakeholders throughout civil society (articles 42-55). In her closing remarks UNCSD President Dilma Rousseff hailed the gathering as "a global expression of democracy" due to its inclusive and participatory nature (Earth Negotiations Bulletin, 2012). This increased focus on civil society was a major change compared with the UNCHE, where NGOs were forced to organize their own parallel meeting. It was not until Rio in 1992 that civil society was let into the official debate. Of course, not all UN members are equally supportive of expanded civil society participation; in particular, some nondemocratic countries continue to be skeptical of involving nonstate actors (Thoyer and Martimort-Asso, 2007). Nevertheless, there is growing belief within the UN system that including civil society groups helps ensure transparency while increasing legitimacy and societal support for sustainability transitions across governance levels.

Changes in official state rhetoric over the past few decades have resulted in a slow but incremental shift toward greater conference participation and influence of nonstate actors. Reflecting this trend, approximately 44000 badges were issued for official meetings at the UNCSD, making it one of the largest ever political meetings (Earth Negotiations Bulletin, 2012). According to The Future We Want, states "agree to work more closely" with stakeholder groups in the areas of planning, decision making, and implementation, but with the important caveat "where appropriate" (article 43). Furthermore, The Future We Want provides little clarification as to what authority will be delegated to nonstate actors or how this will take place. While a growing number of nonstate actors have been given more room to express their opinions and be directly involved in UN processes, many NGOs continue to complain of restricted participation in policy making, as the UN system remains largely state-centric.

Compared with the other conferences, the UNCSD also focused more on the private sector, as The Future We Want declared that a primary role of international institutions is to promote national policies that "foster a dynamic and well-functioning business sector, and to facilitate entrepreneurship and innovation" (article 268). Over the past few decades there has been a gradual shift from legally binding approaches to greater reliance on voluntary action and commitments in the UN system. In particular, since the WSSD, increased attention has been paid to the role of public-private partnerships (so-called type-II agreements), as The Future We Want called for a mix of regulatory and voluntary measures promoting sustainable development. Over 700 voluntary commitments were registered and announced by governments, businesses, and other civil society partners at the UNCSD. Proponents of partnerships hope that more private sector funds will complement public financing, including resources committed to official development assistance. It is, however, unclear how many of the voluntary pledges at the UNCSD and elsewhere will be fulfilled and what kind of impact they will have.

In addition, institutional participation debates are tied to discussions of the need for improved implementation (articles 252-280). At the Nairobi meeting in 1982 it was already obvious there had been limited progress integrating environment and development issues on the ground (Linnér and Selin, 2005). The 1992 Rio meeting was intended to reignite the environment and development agenda, using Agenda 21 as a roadmap. However, in Johannesburg in 2002 it became apparent that states had once again come up short in meeting critical Agenda 21 policy goals. Against this backdrop, yet another push for improved 
implementation at the UNCSD included discussions of the formulation of concrete SDGs originally championed by Colombia and Guatemala and supported by many civil society groups (articles 245-251). In the next section we discuss how the idea of SDGs relates to debates about how to measure economic and human development, including how policy initiatives developed outside the conference system fed into and shaped discussions and decisions at the UNCSD.

\section{A green economy for sustainable development and poverty eradication}

The focus at the UNCSD on a green economy reflects the significance and influence of economic organizations and policies to the sustainable development agenda. Socioeconomic issues have been highly controversial at all UN conferences, and the green economy was one of the most contentious issues at the UNCSD. With reference to sustainable development and poverty eradication, The Future We Want did not specify policies for realizing a green economy, but only offered the broad statements and principles expected in a conference document. Comparing UNCED with previous conferences reveals both continuities and shifts in economic debates and perspectives. The international economic system in the early 2010s also differs greatly from that of 1972. Over the past forty years trade has expanded significantly, financial markets have been deregulated, and newly economically powerful states have emerged. In this section we examine two major aspects of green-economy-related discussions: (i) state-centered economic debates and (ii) human-development-focused debates.

\section{State-centered economic debates}

The term 'green economy' may be relatively new in international politics, but many of the specific topics captured by this rubric have attracted international attention since at least the mid-20th century. Many state-centered socioeconomic issues have been central to the international environment and development debate since the very early days of UN-sponsored conferences. The UNCSD preparatory work exposed crucial controversies over what constitutes a green economy. Championed by UNEP and with strong support from the European Union and many civil society groups, changing the economic pillar of sustainable development is believed by many to be crucial. However, China and other developing countries feared that too stringent green economy language and mandates would restrict the rights of developing countries to choose their own development models and targets (Clémençon, 2012b; Earth Negotiations Bulletin, 2012). These developing country concerns about development-related restrictions are longstanding.

At the Stockholm Conference developing countries stressed that the Global North should not use environmental concerns as an excuse to impose development restrictions on the Global South, which should be given the same opportunity for economic growth as the Global North had already enjoyed. Many developing countries threatened to boycott the Stockholm Conference out of apprehension that it would promote 'environmental neocolonialism' (Selin and Linnér, 2005). As a central part of the preparations for the Stockholm Conference the 1971 Founex Report identified two types of environmental problems: those stemming from unrestricted development (North) and those relating to a lack of development (South) (Rambach, 1972). This observation reflects an early focus on economic growth and poverty eradication, and much of the related debate was state-centered. Principle 9 of the Stockholm Declaration stated that environmental problems resulting from 'underdevelopment' were best addressed by increased development, including "through the transfer of substantial quantities of financial and technological assistance as a supplement to the domestic effort of the developing countries" (UN, 1972).

Shortly after the Stockholm Conference, demands for a New International Economic Order (NIEO), referring to dependency theory, reached a high point. The 1974 UNEP-supported 
symposium on Patterns of Resource Use, Environment and Development Strategies in Cocoyoc, Mexico revisited environment and development issues (Selin and Linnér, 2005). The Cocoyoc Declaration provided an important backdrop to calls for an NIEO, supported by a UN General Assembly resolution in the same year. The Cocoyoc symposium was also connected with the Founex meeting and its attempt to reconcile environmental and development priorities. It provided a strong critique of international trade and investment patterns. Critics argued that international economic relationships served to exploit developing countries, which provided cheap labor and raw materials for multinational firms headquartered in industrialized countries. Many policy proposals focused on increased regulations and state-based controls of capitalist forces alongside reforms of trade and investment rules. Developing countries also called for increased foreign aid with less conditionality.

As the calls for an NIEO faded, most international political efforts since the 1980s have focused on 'greening' capitalism as the neoclassical economic agenda took over. Throughout these ideological changes the focus on generating economic growth has remained steadyalthough theories and perspectives on how best to do this have differed greatly. Voicing a still dominant opinion, World Bank President, former US Secretary of Defense, Robert McNamara, argued at the Stockholm Conference that improved environmental protection and management would be impossible without continued economic growth in both industrialized and developing countries (Rowland, 1973). From the neoclassical perspective currently embraced by most states and leading economic IGOs, expansions in trade and investment are positive in that they help generate growth that will make everyone better off in the long run (although wealth can differ markedly between people and countries). From this perspective the role of politics is largely to facilitate market-based interactions and exchanges.

Over the past forty years funding for environment and development has been a central issue often split along the North-South fault line. The UN General Assembly, during the UN's Second Development Decade extending through the 1970s, set a target of $1 \%$ of GDP to be committed to official development assistance. Even during preparations for the Stockholm Conference, developing countries argued strongly for 'additionality' - the idea that international resources spent on the environment should be additional to those resources already earmarked for development assistance. Developing countries, however, have expressed continued disappointment at the level of financing for both environment and development (Najam, 2011). In the Founex Report and at the Stockholm Conference developing countries, moreover, expressed concerns over environment-related trade protectionism, arguing that environmental concerns should not be used as an excuse for protecting farmers and industries in industrialized countries against cheaper imports from developing countries (Rambach, 1972; Rowland, 1973).

The Brundtland Commission report and the 1992 Rio conference drew renewed attention to linkages between the economy and the environment, as neoclassical economic thinking was increasingly taking over (Clapp and Helleiner, 2012). The Brundtland Commission argued that the concept of sustainable development contained two key dimensions that attempted to take account of both developing and industrialized countries' concerns. The first was the concept of 'needs', particularly the essential needs of the world's poor, to which overriding priority should be given. The second was the idea of 'limitations' imposed by the state of technology and social organization on the environment's ability to meet present and future needs. The Brundtland Report expressed grave concerns about global inequalities, noting that the decade since the Stockholm Conference had been "marked by a retreat from social concerns" and stated that the poorest countries were trapped in a "downward spiral of linked ecological and economic decline" (World Commission on Environment and Development, 1987, page 6). 
As the international economic agenda based on free market expansion and deregulation has become dominant, many current state-centered economic debates are taking place against the backdrop of a fundamental change in international economic relationships in which larger developing countries (including China) have actively sought and gained membership and greater influence in the main multilateral economic organizations. More and more countries see domestic economic growth dependent on being more deeply integrated in transnational production and consumption chains as international trade continues to grow. In Rio in 1992 there was some debate about trade restrictions, but the perceived positive aspects of free trade dominated the discussions. In Johannesburg in 2002 trade was also seen mostly as an opportunity for growth, including as a means to facilitate technology transfer. Against this dominant trend in international political economy it is not surprising that the UNCSD denounced trade distortion and hailed trade as an engine of the shift toward sustainable development.

\section{Human-development-focused debates}

Although international political-economy debates since the 1960s have focused on state conditions and relationships, human development issues have also long been considered. The preamble of the UN Charter stresses the importance of the "promotion of the economic and social advancement of all peoples" (UN, 1945, page 1). The Stockholm Conference further established increasing human capabilities for a life of dignity and well-being as a critical objective (UN, 1972, principle 1). Similar individual-focused goals have been formulated at subsequent environment and development conferences in Rio and Johannesburg and also carried over into the green economy discussions at the UNCSD. However, it is largely outside the major UN meetings that the shift from declarations to formulating more tangible indicators has occurred. In this process the first Human Development Report written under the auspices of the UNDP and published in 1990 was an important event in redirecting at least some of the state-centric environment and development debates back toward a more human-oriented perspective.

The first Human Development Report — which has been followed by annual updateswas drafted by a team led by Pakistani economist Mahbub ul Haq, also a member of the Founex Group examining issues of the human environment in the run-up to the Stockholm Conference (Engfeldt, 2009). In contrast to a traditional GDP approach to measuring national economic growth, the report defined human development as "a process of enlarging people's choices" (UNDP, 1990, pages 9-10). In this respect it marked an important discursive shift toward strengthening individuals' capacity to control their own lives (Thérien, 2012). Furthermore, the UNDP launched the Human Development Index "to shift the focus of development economics from national income accounting to people centered policies" (ul Haq, 1995, page 9). Despite some criticism of the Human Development Index for being too simplistic and lacking clear environmental indices, it did help broaden how development issues were viewed in the context of sustainability (Sagara and Najam, 1998).

In line with the thinking that underlay the Human Development Index, The Future We Want questioned the dominance of GDP as a measure of sustainable development, as the document charged the UN Statistical Commission with proposing "broader measures of progress to complement GDP in order to better inform policy decisions" (article 38). This recommendation responded to those calling for an alternative definition of growth to that found in neoclassical economics, as they advocate more nuanced conceptualizations of what constitutes 'desirable' progress. This perspective is also related to environmental economics, paying greater attention to market failures and externalities as they relate to natural resource use and pollution. Critics of GDP also stress the social dimensions of economic inequality. They argue that only by bringing environmental and social concerns more into 
the center of economic policy making can there be significant progress on sustainable development (UNDP, 2010; United Nations Secretary-General's High-Level Panel on Global Sustainability, 2012).

It is in connection with this increased focus on human development and security, particularly since the 1990s, that the UNCSD debated establishing SDGs. The more comprehensive outlook on human development expressed in the Human Development Reports and the Human Development Index had already fed into the formulation of the MDGs adopted in 2000 (Fukuda-Parr and Hulme, 2011). Together with the seven other goals of eradicating extreme poverty and hunger; achieving universal primary education; promoting gender equality and empowering women; reducing child mortality; improving maternal health; combating HIV/AIDS, malaria, and other diseases; and developing a global partnership for development, ensuring environmental sustainability was one of eight MDG goals. In contrast to the Stockholm Action Plan and Agenda 21, which lacked clear ways to measure progress, the MDGs used a set of twenty-one targets and sixty indicators to review and monitor implementation. The perceived success of the MDGs incited the idea and planning for SDGs using a similar approach (United Nations Secretary-General's High-Level Panel on Global Sustainability, 2012).

Debates about the SDGs highlight the social aspects of sustainable development, including issues of intragenerational and intergenerational equity (Sachs, 2012). Here, too, there are many connections to earlier efforts. Social equity issues were addressed at the Stockholm Conference and were central to many Brundtland Commission recommendations. However, important perspectives on and formulations of the social pillars have changed over time. The Stockholm Declaration and Action Plan drew attention to social risks and benefits, but did little beyond identifying these as major issues. Importantly, The Future We Want raised the standards for social development by calling for the establishment of a social protection floor (article 23). Furthermore, explicit references to social issues were three times more common in The Future We Want outcomes than in the Stockholm Declaration, relative to the length of the two texts. This signals an important recognition of equity and fairness issues to those who have found that the social pillar has not always received enough attention in the sustainable development debate.

In addition, developing countries insisted that poverty eradication should be linked to any green economy debate. Poverty has been on all conference agendas since Stockholm, but remains an enormous problem. People in most parts of the world have benefited from higher incomes from economic growth; but, since the 1980s, income inequality has increased in many more countries than those in which it has decreased (UNDP, 2010). The richest $2 \%$ of adults own more than half of all global wealth, with the richest $1 \%$ controlling $40 \%$ of global assets. In contrast, the bottom $50 \%$ holds barely $1 \%$ of global wealth (Davies et al, 2008). On average, people in the top $10 \%$ are almost 400 times richer than the bottom 50\%, while those in the top $1 \%$ are almost 2000 times wealthier. The World Bank estimates that nearly 1.3 billion people live on less than US $\$ 1.25$ a day (below the extreme poverty line). Close to 2.5 billion people - more than one third of the global population-survive on less than US \$2 a day. All these data highlight the urgency of more aggressively addressing poverty and hunger.

\section{Rio revisited}

The UN system of organizing large conferences on environment and development, of which the UNCSD is the most recent example, has been criticized for its inability to generate sufficient on-the-ground progress. This kind of criticism raises issues about what can reasonably be expected from global conferences. If it is hoped that they will 'solve' the sustainable development problem, then they will always be seen as coming up short. 
This is an unrealistic view of what UN forums can accomplish. More pragmatically, UN meetings can at their best help set and steer economic, social, and environmental agendas and lay a foundation for expanded cooperation. The conferences have also acted as important catalysts of domestic action. The Stockholm Conference stimulated countries all over the world to assess environmental conditions and take legal and organizational steps, including creating environmental ministries and protection agencies. Similarly, subsequent conferences inspired countries to consider how to address sustainable development issues at the national and local levels.

Major metrics of environmental conditions and human well-being indicate a mixed situation. The world is both a much better and a much worse place today than in 1972 . Many global ecological trends are negative, including growing greenhouse gas emissions, continuing biodiversity loss, declining fish stocks, and higher waste levels. At the same time, there have been steep reductions in emissions of ozone-depleting substances and levels of oil pollution at sea (UNEP, 2012). The record on human indicators is similarly mixed. More people live longer, are healthier and better educated, and have greater access to basic goods and services than they did forty years ago (UNDP, 2010). Child mortality is declining, the spread of tuberculosis has been halted, and the rate of malaria deaths has fallen. However, the number of people living in slums continues to grow, and over 600 million people lack access to safe drinking water and basic sanitation (UN, 2012). Furthermore, there are striking variations in progress in human development across countries and regions.

In the face of this extremely complex and dire situation, how may the UNCSD shape ongoing efforts to advance the sustainable development agenda? The UN conferences remain important forums for global agenda setting and transparent debate. However, institutional change to close the implementation gap has been incremental at best. Like earlier conference documents, The Future We Want is very vague as to how to move from paper to practice. Constrained by path dependency and conflicting interests, UNCSD decisions (once again) called for only limited institutional reform, There remains important opposition to strengthening UNEP's mandate, and it seems unlikely that the new 'high-level political forum' replacing the CSD will represent a substantial institutional change. Furthermore, there is little political appetite for anything but very modest change (if any) to 'greening' the operations of the WTO and other main economic organizations. Nevertheless, it is clear that the long-term influence of the UNCSD is in part tied to the extent to which public, private, and civil society actors are willing to reform political and economic institutions (Biermann, 2013).

In contrast, more progress occurred on human development, drawing heavily from processes outside the conference system. The MDGs show that UN initiatives can stimulate real progress. Some MDGs will be met or even exceeded while a few will be missed (UN, 2012). Building on both positive and negative lessons from how the MGDs were formulated and implemented, the SDGs could be important for steering international and national actions (Sachs, 2012). Whereas the MDGs focused on the world's developing countries, all countries would be covered by the SDGs. In fact, any SDGs relating to natural resource consumption and ecological footprints would put the spotlight on industrialized countries. Exactly what the SDGs should cover, how they should be formulated, and how implementation should be measured and reported are subject to heated political debates, as the thirty-member working group tasked to consider these critical issues will report to the UN General Assembly in 2014. Effective use of indicators to track progress is central, and the extent to which the SDGs move the sustainable development agenda forward will significantly affect how analysts eventually judge the UNCSD.

As the work on the SDGs continues, it is uncertain how shifting political and economic relationships among states will affect the formulation of obligations and responsibilities across 
a wide range of sustainable development issues (Perkins, 2013). Clémençon (2012a) calls for more leadership from industrialized countries, but argues that the United States is right in insisting on a more differentiated assessment of countries' responsibilities than a simple division between industrialized and developing countries. This also affects funding issues. Sachs (2012) argues that, whereas the MDGs relied on voluntary aid funding, the SDGs should come with transparent and specific financing standards based on mandatory quotas and assessments. A related key question is whether states are prepared to address inequalities within and between nations and put intragenerational and intergenerational equity at the very center of the sustainable development agenda (Najam and Selin, 2011). In this and other areas the UN will continue to be important; but, as in the aftermath of all UN conferences, concrete changes will have to happen at mostly regional, national, and local levels.

Acknowledgements. This research was supported by the Swedish Research Council formas project 'Non-state actors in the new landscape of international climate Cooperation' (2011-779). We would like to thank Richard Perkins and two anonymous reviewers for helpful comments and suggestions on earlier versions of the text.

\section{References}

Andresen S, 2012, "Do we need more global sustainability conferences?", in Handbook of Global Environmental Politics 2nd edition Ed. P Dauvergne (Edward Elgar, Cheltenham, Glos) pp 87-96

Bernstein S, 2001 The Compromise of Liberal Environmentalism (Columbia University Press, New York)

Biermann F, 2010, "Beyond the intergovernmental regime: recent trends in global carbon governance" Current Opinion in Environmental Sustainability 2 1-5

Biermann F, 2013, "Curtain down and nothing settled: global sustainability governance after the 'Rio+20' Earth Summit" Environment and Planning C: Government and Policy 31 1099-1114

Biermann F, Bauer S (Eds), 2005 A World Environment Organization: Solution or Threat for Effective International Environmental Governance? (Ashgate, Aldershot, Hants)

Bigg T, 2011, "Development governance and the green economy: a matter of life and death?" Review of Policy Research 28 459-465

Cerney P G, 2010 Rethinking World Politics: A Theory of Transnational Neopluralism (Oxford University Press, Oxford)

Clapp J, Helleiner E, 2012, "International political economy and the environment: back to basics? International Affairs $\mathbf{8 8}$ 485-501

Clémençon R, 2012a, "Welcome to the anthropocene: Rio+20 and the meaning of sustainable development" Journal of Environment and Development 21 311-338

Clémençon R, 2012b, "From Rio 1992 to Rio 2012 and beyond: revisiting the role of trade rules and financial transfers for sustainable development" Journal of Environment and Development $215-14$

Cordier A W, Harrelson M, 1977 Public Papers of the Secretaries-General of the United Nations, Volume VIII, U Thant 1968 - 1971 (Columbia University Press, New York)

Davies J B, Sandström S, Shorrocks A, Wolff E N, 2008, “The world distribution of household wealth", DP 2008/03, United Nations University, Tokyo

Death C, 2011, "Summit theatre: exemplary governmentality and environmental diplomacy in Johannesburg and Copenhagen" Environmental Politics 20 1-19

DeSombre E R, 2006 Global Environmental Institutions (Routledge, New York)

Dodds F, Strauss M, Strong M, 2012 Only One Earth: The Long Road Via Rio to Sustainable Development (Routledge, New York)

Earth Negotiations Bulletin, 2012, "Summary of the United Nations Conference on Sustainable Development, 13-22 June 2012”, International Institute for Sustainable Development, Winnipeg, MB

Eckersley R, 2012, "Moving forward in the climate negotiations: multilateralism or minilateralism" Global Environmental Politics 12 24-42 
Engfeldt L-G, 1973, "The United Nations and the human environment: some experiences" International Organization 27 393-412

Engfeldt L-G, 2009 From Stockholm to Johannesburg and Beyond: The Evolution of the International System for Sustainable Development Governance and Its Implications The Government Offices of Sweden, Stockholm

Faucheux S, Pearce D, Proops J, 1996 Models of Sustainable Development (Edward Elgar, Cheltenham, Glos)

Fiertos O, 2011, "Historical institutionalism in international relations" International Organization $65367-395$

Fukuda-Parr S, Hulme D, 2011, "International norm dynamics and the 'end of poverty': understanding the Millennium Development Goals" Global Governance 17 17-36

Goodland R, 1995, "The concept of environmental sustainability" Annual Review of Ecology and Systematics 26 1-24

Guha R, Martinez-Alier J, 1997 Varieties of Environmentalism: Essays North and South (Earthscan, London)

Haas P M, 2012, "The road from Rio: why environmentalism needs to come down from the summit" Foreign Affairs 16 August, http://www.foreignaffairs.com/articles/138031/peter-m-haas/the-road-from-rio

Hafner-Burton E M, Victor D G, Lupa Y, 2012, "Political science research on international law: the state of the field" American Journal of International Law 106 47-97

Hjerpe M, Linnér B-O, 2010, "Functions of COP side-events in climate-change governance" Climate Policy 10 167-180

Holdgate M, 1999 The Green Web: A Union for World Conservation (Earthscan, London)

Howarth R B, 1997, "Defining sustainability: an overview" Land Economics 73 445-447

Ivanova M, 2007, "Designing the United Nations Environment Programme: a story of compromise and confrontation" International Environmental Agreements: Politics, Law, and Economics $7337-361$

Ivanova M, 2012, "Institutional design and UNEP reform: historical insights on form, function and financing" International Affairs $\mathbf{8 8} 565-584$

Jordan A, 2008, "The governance of sustainable development: taking stock and looking forwards" Environment and Planning C: Government and Policy 26 17-33

Kaasa S M, 2007, "The UN Commission on Sustainable Development: which mechanisms explain its accomplishments?" Global Environmental Politics 7 107-129

Kahler M, 1992, "Multilateralism with small and large numbers" International Organization 46 681-708

Lele S M, 1991, "Sustainable development: a critical review" World Development 19 607-621

Linnér B-O, Selin H, 2005, "The road to Rio: early efforts on environment and development", in Global Challenges: Furthering the Multilateral Process for Sustainable Development Eds A Churie Kallhauge, G Sjöstedt, E Corell (Greenleaf Publishing, London) pp 58-73

McGrew A, Held D, 2002 Governing Globalization: Power, Authority and Global Governance (Polity Press, Cambridge)

Meléndez-Ortiz R, 2011, “Governance of trade for the green economy" Review of Policy Research 28 479-486

Meyer J W, Frank D G, Hironaka A, Schofer E, Brandon Tuma N, 1997, "The structuring of a world environmental regime" International Organization 51 623-651

Olson M, 1968 The Logic of Collective Action (Schocken, New York)

Najam A, 2011, "The view from the south: developing countries in global environmental politics", in The Global Environment: Institutions, Law, and Policy Eds R S Axelrod, S D Vandeveer, D L Downie (CQ Press, Washington, DC) pp 239-258

Najam A, Selin H, 2011, "Institutions for a green economy” Review of Policy Research 28 451-457

Perkins R, 2013, "Sustainable development and the making and unmaking of a developing world" Environment and Planning C: Government and Policy 31 1003-1022

Powers A, 2012, "The Rio+20 process: forward movement for the environment?" Transnational Environmental Law 1 403-412 
Quental N, Lourenço J M, Nunes da Silva F, 2011, "Sustainable development policy: goals, targets and political cycles" Sustainable Development 19 15-29

Rambach P, 1972, "Founex Report on Development and Environment" International Conciliation $5867-36$

Rowland W, 1973 The Plot to Save the World (Clarke, Irwin, Toronto, ON)

Sachs J D, 2012, "From Millennium Development Goals to sustainable development goals" The Lancet 379(9832) 2206-2211

Sachs W, 1993, "Global ecology and the shadow of development", in Global Ecology: A New Arena of Political Conflict Ed. W Sachs (Zed Books, London) pp 3-21

Sagara A D, Najam A, 1998, "The human development index: a critical review” Ecological Economics 25 249-264

Schechter M G, 2005 United Nations Global Conferences (Routledge, New York)

Seyfang G, 2003, "Environmental mega-conferences: from Stockholm to Johannesburg and beyond" Global Environmental Change 13 223-228

Selin H, 2010 Global Governance of Hazardous Chemicals: Challenges of Multilevel Management (MIT Press, Cambridge, MA)

Selin H, Linnér B-O, 2005, "The quest for global sustainability: international efforts on linking environment and development", WP 5, Science, Environment and Development Group, Center for International Development, Harvard University, Cambridge, MA

Thérien J-P, 2012, "The United Nations and human development: from ideology to global policies" Global Policies 3 1-12

Thoyer S, Martimort-Asso B, 2007 Participation for Sustainability in Trade (Ashgate, Aldershot, Hants)

ul Haq M, 1995 Reflections on Human Development (Oxford University Press, New York)

UN, United Nations, New York

1945 Charter of the United Nations: We the Peoples of the United Nations San Francisco, CA

1972a, "Report of the United Nations Conference on the Human Environment", Stockholm, 5-16 June, A/CONF.48/14 and corr.1

1972b, "General Assembly A/PV 2112, agenda item 47, United Nations Conference on the Human Environment: report of the Secretary-General", 15 December, United Nations General Assembly

1992a, "Rio Declaration on Environment and Development", report of the United Nations Conference on Environment and Development, Rio de Janeiro, 3-14 June, annex 1,

A/CONF.151/26 (vol. I), 12 August, United Nations General Assembly

1992b, “Agenda 21", United Nations Conference on Environment and Development,

Rio de Janerio, Brazil, 3-14 June

2002, "Report of the World Summit on Sustainable Development", Johannesburg,

26 August-4 September, A/CONF.199/20, United Nations General Assembly

2012 The Millennium Development Goals Report 2012

UNDP, United Nations Development Programme, New York

1990 Human Development Report 1990: Concept and Measurement of Human Development (Oxford University Press, Oxford)

2010 Human Development Report 2010: The Real Wealth of Nations-Pathways to Human Development

2013 Human Development Report 2013: The Rise of the South-Human Progress in a Diverse World

UNEP, 2012. Global Environment Outlook 5: Environment for the Future We Want. United Nations Environment Programme, Nairobi

UNGA, 2010 Implementation of Agenda 21, the Programme for the Further Implementation of Agenda 21 and the Outcomes of the World Summit on Sustainable Development resolution A/RES/64/236 adopted by the General Assembly, United Nations General Assembly

UNGA, 2012 The Future We Want resolution A/RES/66/288 adopted by the General Assembly, United Nations General Assembly 
United Nations Secretary-General's High-Level Panel on Global Sustainability, 2012 Resilient People, Resilient Planet: A Future Worth Choosing (United Nations, New York)

Vijge M J, 2013, "The promise of new institutionalism: explaining the absence of a world or United Nations environment organisation" International Environmental Agreements 13 153-176

World Commission on Environment and Development, 1987 Our Common Future (Oxford

University Press, Oxford) 